\title{
Nutritional and non-nutritional habits and occurrence of malocclusions in the mixed dentition
}

\author{
ELIANE TRAEBERT, FRANCIELLE A. ZANINI, RODRIGO D. NUNES \& \\ JEFFERSON TRAEBERT
}

\begin{abstract}
Malocclusions are changes in the development of craniofacial structures of high prevalence. Associated risk factors are diverse and nutritional and non-nutritional suction habits are the most reported. The aim of this study was to estimate the prevalence of malocclusions in the mixed dentition and to study possible association with practices of breastfeeding and suction habits among Brazilian schoolchildren. A cross-sectional study involving a sample of 664 6-year-old children and their families was carried out. Data collection was done through interviews with mothers in the homes and oral examinations of children in schools. Multivariate analyses were performed using the Poisson regression with a robust estimator. The prevalence of overjet over $4 \mathrm{~mm}$ was $21.1 \%$ and of posterior crossbite was $12.2 \%$; $91.9 \%$ of the children were breastfed, $79.0 \%$ used a nursing bottle and $49.4 \%$ used a pacifier. Significant and independent associations were observed between father's unemployment, private school, interruption of breastfeeding before the fourth month and pacifier use with certain malocclusions. High rates of malocclusion were found in the studied sample. Socioeconomic conditions, breastfeeding practices and suction habits were shown to be statistically associated with their occurrence.
\end{abstract}

Key words: malocclusions, breast-feeding, suction habits, schoolchildren.

\section{INTRODUCTION}

Malocclusions are development changes which occur in craniofacial structures involving bones, tongue and muscles (WHO 2013). They may cause facial deformities, functional or aesthetic alterations compromising people's life quality (Peres et al. 2009).

The prevalence of malocclusions is high and, consequently, they may be considered a public health concern, since they demand treatment and may cause social impact (Peres et al. 2002). In Brazil, according to data from the latest epidemiologic study conducted in 2010 at national level, malocclusions represented one of the most prevalent dental health problems. The prevalence of any type of malocclusion in primary dentition in 5-year-old children was $66.7 \%$ and $37.6 \%$ in the permanent dentition in 12-year-olds (Brasil 2011). A study using this national data showed higher probability of occurrence of malocclusion in 5-year-old children resident in the Midwest, Northeast, Southeast and South Brazilian regions when compared to residents in the North. It was also higher among female children. No associations were identified concerning race and location of the municipality of residence (Bauman et al. 2018). 
There are a number of risk factors associated with development of malocclusions in childhood, suction habits being the most reported. Suction habits may be classified as nutritional, as breastfeeding practices and the use of nursing bottles, or non-nutritional, as thumb-sucking or pacifier sucking (Bueno et al. 2013, Moimaz et al. 2014, Sousa et al. 2014, Chen et al. 2015, Peres et al. 2015).

Malocclusions are more common in preschool age children who have a record of nursing bottle using and other non-nutritional suction habits (Correa-Faria et al. 2013, Bueno et al. 2013, Moimaz et al. 2014, Peres et al. 2015). This kind of oral habits may interfere in the development and growth of the cranial bone and not only in the dental position (Grippaudo et al. 2016). The use of pacifiers was found to be very important for the development of malocclusions, mainly anterior open bite and posterior crossbite (Sousa et al. 2014). The risk does not depend, however, only on the habits, but also on the genetic growth pattern, since not every individual with the same habits will present occlusal problems in the future (Grippaudo et al. 2016).

Besides suction habits, respiratory tract alterations may also contribute to the development of malocclusions. Mouth breathing due to nasal obstruction may lead to changes in the posture and positioning of tongue and lips, which may generate vertical increase of the face (Sousa et al. 2005). Furthermore, it is related to different malocclusions, as increased overjet, anterior and posterior crossbite and anterior open bite (Grippaudo et al. 2016).

Currently, the knowledge about the importance of breastfeeding, both for the child and the mother, is very advanced. The decision of not breastfeeding brings consequences to health development (Amaral et al. 2017). Breast suction during breastfeeding involves several muscles and this recruiting is related to oral and facial development, culminating in the correct development of these structures (Chen et al. 2015). Moreover, exclusive breastfeeding is related to a lower chance of development of non-nutritional suction habits, as the use of pacifiers (Lopes-Freire et al. 2015, Peres et al. 2015). However, in many cases this is not just a matter of choice by the mother. Amaral et al. (2015) indicate factors that hinder or prevent breastfeeding, among them, the lack of knowledge of mothers about breastfeeding, the belief in insufficient milk production, difficulty of breast grabbing by the child, complications with the newborn and breast complications.

Although there is already a relative knowledge on the association between malocclusion and pacifier use, there is still a need for further studies on nutritional and nonnutritional habits and its occurrence, especially the role of breastfeeding in its prevention. Also, as it is very important to have epidemiological data for health planning, the objective of this study was to estimate the prevalence of malocclusions and to study possible association with practices of breastfeeding and suction habits.

\section{MATERIALS AND METHODS}

A cross-sectional study nested in a cohort study named Coorte Brasil Sul (Traebert et al. 2018) was carried out. The population was composed by 6 -year-old children and their families, living in Palhoça/SC, southern Brazil and regularly enrolled in public and private schools of the city in 2015. The majority of the kids were enrolled in the first year of elementary school.

The minimum number of the sample was determined through the following parameters: total population of 1,756 schoolchildren; 
confidence level of 95\%; unknown prevalence of outcomes studied ( $P=50 \%$ ); relative error of $3 \%$. The total number of the sample was of 664 children and their families.

Data collection was carried out through interviews and oral exams of the kids in 2015. Families were invited to participate in the study by a letter containing the purpose of the study sent through the schools. Local radio stations, newspapers and other available media were used to disseminate information and call for participation (Traebert et al. 2018).

The interviews were made with the mother or, in her absence, the main caregiver of the child, at home, by Community Health Agents and by Coorte Brasil Sul's research team. Community Health Agents were professionals from the municipality City Hall of Palhoça, responsible for household and community health promotion actions with the population in the context of the Family Health Strategy of the Brazilian Unified Health System (Sistema Único de Saúde). The researchers of the Coorte Brasil Sul study were undergraduate and postgraduate students from the Universidade do Sul de Santa Catarina. The research team underwent a training process with 30 hours/activities. The training focused on data collection strategies in epidemiological studies emphasizing the interview processes in order to minimize possible measurement biases (Traebert et al. 2018). Variables included in the interviews were number of mothers' and fathers' finished years of schooling (after categorized in less than 8 years and over 8 years, indicating at least incomplete or complete elementary school); mothers' and fathers' occupation (employed or unemployed); marital status (with or without steady partner); if child had attended day care in the first two years of life (yes or no); if exclusive breastfeeding had been interrupted before the $4^{\text {th }}$ or the $6^{\text {th }}$ month (yes or no); if child had used nursing bottle or pacifier at any time (yes or no); child digital suction at any time (yes or no); child mouth breathing at any time (yes or no). The questionnaire used in the interview was developed by a committee composed of 3 PhD professors and 5 doctoral students from the Postgraduate Program in Health Sciences of Universidade do Sul de Santa Catarina (Traebert et al. 2018).

Oral examinations of the children were conducted in the 56 schools of the city by eight dentists, who performed oral examination of kids and eight dental nurses, who performed the role of note takers and organizers. For the clinical exams to take place, the team was enabled and calibrated so as to minimize potential diagnosis biases (Peres et al. 2001). For all studied clinical situations Kappa values were higher than 0.7, which means that the team achieved a good level of inter and intra-examiner diagnostic reproducibility (Landis \& Koch 1977). All biosecurity standards were rigorously met.

For the assessment of malocclusions, adapted Summers index (Summers 1971) for mixed dentition was used. The adaptation consisted of the exclusion of the diastema measures, posterior open bite, midline deviation, upper and lower tooth displacement and loss of permanent incisors. They are justified by the fact that these measures are not definitive in the six-year-old children, since the incisors are in eruption stage. The maintenance of these measures might lead to the occurrence of diagnostic bias. The conditions related to the anterior open bite and the anterior crossbite were noted as presence or absence, as measures in millimeters were registered in the conditions of overjet and overbite, respectively. A clinical and epidemiological record was especially developed for the study.

A pilot study was conducted involving 10\% of the total sample $(n=65)$ aiming to test the 
proposed methodology. It was observed that no substantial changes were needed.

Data collected were initially organized in Excel spreadsheets and later exported to SPSS ${ }^{\circledR} 18.0$ where they were analyzed. The outcome was different types of malocclusions: class II or III molar/canine relationship; overjet $\geq 4 \mathrm{~mm}$; overbite $\geq 4 \mathrm{~mm}$; posterior crossbite; anterior open bite and anterior crossbite. The independent variables were child's gender; mother's and father's schooling; mother's and father's ocuppation; steady partner; type of school; interruption of exclusive breastfeeding before the $4^{\text {th }}$ and the $6^{\text {th }}$ month; use of nursing bottle or pacifier at any time; digital suction and mouth breathing report. Bivariate analyses were performed by chi-square test with $p<0.05$. The multivariate analysis included all the variables with $p \leq 0.20$ in the bivariate analysis through Poisson regression with robust estimator. The final models were elaborated using the stepwise backward method, so that all significant variables had their effect adjusted. In the final models, variables with a significance level less than or equal to 0.05 were maintained. Prevalence ratios (PR) and their respective confidence intervals (CI) at $95 \%$ were calculated.

The research project of this study was submitted to and approved by the Ethics in Research Committee from the Universidade do Sul de Santa Catarina under the protocol $n^{\circ}$ 38240114.0.0000.5369.

\section{RESULTS}

Of the 664 invited families, 655 agreed to participate, which generated a $98.6 \%$ response rate. The mother was the main survey respondent (68.5\%). From the total of included children, 50.5\% were female. It was observed that the median of mother and the father schooling was 10 years.
The percentage of parents who concluded elementary school and other socio-demographic information are presented in Table I.

From the total of kids, 91.9\% was breastfed regardless the period. The breastfeeding time average was 12.5 months. Breastfeeding up to 12 months old was observed in $50 \%$ of the kids and up to 24 months old, in $23.9 \%$

Table II shows aspects related to suction habits of kids. It was observed that $79.0 \%$ used a nursing bottle and $49.4 \%$, a pacifier. Yet, Table III shows the prevalence of the studied malocclusions. Overjet $\geq 4 \mathrm{~mm}$ was found in $21.1 \%$ and anterior open bite, in $14.1 \%$ of kids.

Table IV shows the results of the association studies between malocclusions in the mixed dentition and independent variables. Adjusted final models obtained through Poisson regression are showed in Table $\mathrm{V}$. The presence of Angle class II or III molar/canine relationship showed to be independently associated with the use of pacifier $[\mathrm{PR}=1.27(\mathrm{Cl} 95 \% 1.02 ; 1.58) \mathrm{p}=$ $0.030]$ and reporting of mouth breathing $[P R=$ 1.30 ( $\mathrm{Cl} 95 \% 1.06 ; 1.61) ; p=0.012]$. Overjet $\geq 4 \mathrm{~mm}$ showed to be associated with mouth breathing report $[P R=1.41(\mathrm{Cl} 95 \% 1.09 ; 1.82) ; p=0.012]$. The variables independently associated with posterior crossbite were type of school: children studying in private schools presented 59\% higher prevalence comparing to those studying in public schools [PR $=1.59(\mathrm{Cl} 95 \% 1.01 ; 2.53) ; \mathrm{p}=$ 0.040 ]; interruption of exclusive breastfeeding before the $4^{\text {th }}$ month $[\mathrm{PR}=2.23(\mathrm{Cl} 95 \% 1.44 ; 3.45)$; $\mathrm{p}=0.011]$; and use of pacifier $[\mathrm{PR}=2,13(\mathrm{Cl} 95 \%$ $1.30 ; 3.51) ; p=0.016]$. Variables independently associated with anterior open bite were use of pacifier $[P R=2,65(\mathrm{Cl} 95 \% 1.56 ; 4.50) ; p=0.012]$ and digital suction $[\mathrm{PR}=1,81(\mathrm{Cl} 95 \% 1.03 ; 3.18)$; $p=0.045$ ]. 
Table I. Socio-demographic variables. 6-year-old schoolchildren. Palhoça/SC, Brazil.

\begin{tabular}{|c|c|c|c|}
\hline SOCIO-DEMOGRAPHIC VARIABLES & $\mathbf{n}$ & $\%$ & Cl 95\% \\
\hline \multicolumn{4}{|l|}{ CHILD GENDER $(n=655)$} \\
\hline Male & 326 & 49.5 & $45.7 ; 53.3$ \\
\hline Female & 329 & 50.5 & $46.7 ; 54.3$ \\
\hline \multicolumn{4}{|l|}{ MOTHER'S SCHOOLING $(n=610)$} \\
\hline$\leq 8$ complete years studied & 181 & 29.7 & $26.1 ; 33.3$ \\
\hline$>8$ complete years studied & 429 & 70.3 & $66.7 ; 73.9$ \\
\hline \multicolumn{4}{|l|}{ FATHER'S SCHOOLING $(n=531)$} \\
\hline$\leq 8$ complete years studied & 203 & 38.2 & $34.1 ; 42.3$ \\
\hline > 8 complete years studied & 328 & 61.8 & $57.7 ; 65.9$ \\
\hline \multicolumn{4}{|l|}{ FATHER'S OCCUPATION $(n=599)$} \\
\hline Employed & 563 & 94.0 & 92.1; 95.9 \\
\hline Unemployed & 36 & 6.0 & 4.1; 7.9 \\
\hline \multicolumn{4}{|l|}{ MOTHER'S OCCUPATION $(n=642)$} \\
\hline Employed & 396 & 61.7 & $58.0 ; 65.4$ \\
\hline Unemployed & 246 & 38.3 & $34.6 ; 42.0$ \\
\hline \multicolumn{4}{|l|}{ MARITAL STATUS $(n=646)$} \\
\hline With steady partner & 530 & 82.0 & $79.1 ; 84.9$ \\
\hline Without steady partner & 116 & 18.0 & $15.1 ; 20.9$ \\
\hline \multicolumn{4}{|l|}{ DAY CARE IN THE FIRST TWO YEARS $(n=566)$} \\
\hline Yes & 324 & 57.2 & $53.2 ; 61.2$ \\
\hline No & 242 & 42.8 & $38.8 ; 46.8$ \\
\hline \multicolumn{4}{|l|}{ TYPE OF SCHOOL $(n=655)$} \\
\hline Private & 101 & 15.4 & $12.7 ; 18.1$ \\
\hline Public & 554 & 84.6 & $81.9 ; 87.3$ \\
\hline
\end{tabular}

Cl 95\% = Confidence interval at $95 \%$.

Table II. Prevalence of nutritional and non-nutritional habits in 6-year-old schoolchildren. Palhoça/SC, Brazil.

\begin{tabular}{|c|c|c|c|}
\hline $\begin{array}{l}\text { VARIABLES } \\
\text { INTERRUPTION OF EXCLUSIVE BREASTFEEDING BEFORE THE } 4^{\text {th }} \text { MONTH }(n=586)\end{array}$ & $\mathbf{n}$ & $\%$ & $\mathrm{Cl} 95 \%$ \\
\hline Yes & 154 & 26.3 & $22.8 ; 29.8$ \\
\hline No & 432 & 73.7 & $70.2 ; 77.2$ \\
\hline \multicolumn{4}{|l|}{ INTERRUPTION OF EXCLUSIVE BREASTFEEDING BEFORE THE $6^{\text {th }}$ MONTH $(n=586)$} \\
\hline Yes & 296 & 50.5 & $46.5 ; 54.5$ \\
\hline No & 290 & 49.5 & 45.5; 53.5 \\
\hline \multicolumn{4}{|l|}{ USE OF NURSING BOTTLE $(n=648)$} \\
\hline Yes & 512 & 79.0 & $75.9 ; 82.1$ \\
\hline No & 136 & 21.0 & $17.9 ; 24.1$ \\
\hline \multicolumn{4}{|l|}{ PACIFIER SUCTION $(n=654)$} \\
\hline Yes & 323 & 49.4 & $45.6 ; 53.2$ \\
\hline No & 331 & 50.6 & $46.8 ; 54.4$ \\
\hline \multicolumn{4}{|l|}{ DIGITAL SUCTION (n=652) } \\
\hline Yes & 58 & 8.9 & $6.8 ; 11.0$ \\
\hline No & 594 & 91.1 & $90.0 ; 93.2$ \\
\hline \multicolumn{4}{|l|}{ MOUTH BREATHING REPORT $(\mathrm{n}=652)$} \\
\hline Yes & 358 & 54.9 & $51.7 ; 58.7$ \\
\hline No & 294 & 45.1 & $41.3 ; 48.9$ \\
\hline
\end{tabular}

$\mathrm{Cl} 95 \%$ = Confidence interval at $95 \%$. 
Table III. Prevalence of malocclusions in the mixed dentition among 6-years-old schoolchildren. Palhoça/SC, Brazil.

\begin{tabular}{|c|c|c|c|}
\hline MALOCCLUSIONS & $\mathrm{n}$ & $\%$ & $\mathrm{Cl} 95 \%$ \\
\hline \multicolumn{4}{|c|}{ RELATIONSHIP AMONG MOLARS $(\mathrm{n}=607)$} \\
\hline Class III & 29 & 4.8 & $3.1 ; 6.5$ \\
\hline Class II & 141 & 23.2 & $21.5 ; 24.3$ \\
\hline Class I & 437 & 72.0 & $70.3 ; 73.7$ \\
\hline \multicolumn{4}{|c|}{ RELATIONSHIP AMONG CANINES $(n=634)$} \\
\hline Class III & 40 & 6.3 & $4.5 ; 8.1$ \\
\hline Class II & 108 & 17.0 & $15.2 ; 18.8$ \\
\hline Class I & 486 & 76.7 & $74.9 ; 78.5$ \\
\hline \multicolumn{4}{|c|}{ OVERJET IN mm $(\mathrm{n}=650)$} \\
\hline$\geq 4$ & 135 & 21.1 & $18.0 ; 24.2$ \\
\hline-6 to $-0,5$ & 22 & 3.6 & $0.5 ; 6.7$ \\
\hline 0 & 18 & 2.8 & $0.1 ; 5.9$ \\
\hline 1 to 3 & 475 & 73.1 & $70.2 ; 76.4$ \\
\hline \multicolumn{4}{|c|}{ OVERBITE IN mm (n=649) } \\
\hline$\geq 4$ & 116 & 17.9 & $15.0 ; 20.8$ \\
\hline$-8,5$ to $-0,5$ & 65 & 10.3 & $7.4 ; 13.2$ \\
\hline 0 & 18 & 2.8 & $0.1 ; 5.7$ \\
\hline 1 to 3 & 450 & 69.4 & $66.5 ; 72.3$ \\
\hline \multicolumn{4}{|c|}{ POSTERIOR CROSSBITE $(n=649)$} \\
\hline Presence & 79 & 12.2 & $9.7 ; 14.7$ \\
\hline Absence & 570 & 87.8 & $85.3 ; 90.3$ \\
\hline \multicolumn{4}{|c|}{ ANTERIOR OPEN BITE $(n=652)$} \\
\hline Presence & 92 & 14.1 & $11.5 ; 16.7$ \\
\hline Absence & 560 & 85.9 & $83.3 ; 88.5$ \\
\hline \multicolumn{4}{|c|}{ ANTERIOR CROSSBITE $(n=652)$} \\
\hline Presence & 55 & 8.4 & $6.3 ; 10.5$ \\
\hline Absence & 597 & 91.6 & $89.5 ; 93.7$ \\
\hline
\end{tabular}

$\mathrm{Cl}$ 95\% = Confidence interval at 95\%.

\section{DISCUSSION}

The good response rate and the use of validated measures confer good internal and external validity of the study.

Malocclusions in the mixed dentition showed high prevalence, as $30.6 \%$ of overbite $\geq 4 \mathrm{~mm}, 26.9 \%$ of overjet $\geq 4 \mathrm{~mm}$ and $23.3 \%$ of altered relationship among canines, among others. In Brazil and in the its southern region the prevalence is even higher: $35.6 \%$ and $48.1 \%$ of increased overbite, $31.7 \%$ and $39.3 \%$ of increased overjet and $23.1 \%$ and $29.7 \%$ of altered relationship among canines, respectively (Brasil 2011). Therefore, the study of the association between nutritive and non-nutritive suction habits with occurrence of malocclusions remains relevant especially in populations with high prevalence, as it is in the present study.

The interruption of exclusive maternal breastfeeding before the fourth month was found to be associated with the occurrence of posterior crossbite. A recent meta-analysis 
(Boronat-Catala at al. 2017) concluded that infants who were not breastfed presented 1.7 times more occurrence of posterior crossbite compared to the ones who were breastfed between one to six months. Sousa et al. (2014) found similar results, in which breastfeeding for fewer than 12 months showed to be associated to a higher prevalence of posterior crossbite. Nevertheless, interruption of exclusive breastfeeding before the fourth or the sixth month did not prove to be associated to the other malocclusions in the present study. Bueno et al. (2013) concluded, however, that children who were breastfed for less than six months had 2.78 times higher chance of presenting altered overbite compared to those who were breastfed for seven months or more. Germa et al. (2016) found relationship between breastfeeding time only with the occurrence of anterior open bite. Such differences may possibly be attributed to the different ages of the samples. Nonetheless, breastfeeding is appointed as one of the behavioral factor which provides the correct development of craniofacial structures. If it happens for a short time, the oral musculature does not develop to its full potential and this may lead to the incorrect posture of the lips and tongue (Chen et al. 2015). Breast suction involves several muscles and this recruiting is related to oral and facial development, culminating in correct development of these structures (Chen et al. 2015). Furthermore, exclusive breastfeeding is related to a lower chance of development of non-nutritional suction habits, as the use of pacifiers (Peres et al. 2015).

We reinforce that the World Health Organization and the Brazilian Health Ministry recommend exclusive breastfeeding until the sixth month and then, introduction of complementary feeding along with breastfeeding until age two or older (Sousa et al.
2004). Breastfeeding for longer periods may act as a protector factor against the development of malocclusions, mainly posterior crossbite, which is a type of malocclusion that develops in early age and hardly recedes by itself (Sousa et al. 2014).

The malocclusions which presented association with the use of a pacifier were the presence of class II or III molar/canine relationship, posterior crossbite and anterior open bite, which corroborates with findings from the literature (Moimaz et al. 2014, Sousa et al. 2014, Chen et al. 2015). Chen et al. (2015) found association with increased overjet and lack of space in the jaw. Sousa et al. (2014) stated that the use of a pacifier is a risk factor both for posterior crossbite and increased overjet, especially when the habit persists for more than three years. Moimaz et al. (2014) reported that children who used a pacifier or had digital suction habits presented higher prevalence of increased overjet and open bite. Such alterations are due to interference of the pacifier or the thumb in physiological movements of perioral muscles and tongue (Sousa et al. 2004). Likewise, Peres et al. (2007) concluded that the prolonged use of the pacifier and digital suction showed to be associated to the occurrence of open bite at age six.

In turn, the use of the nursing bottle was not associated to the studied malocclusions in the current sample. Notwithstanding, a recent systematic review (Correa-Faria et al. 2013) showed that the use of the nursing bottle was associated with higher prevalence of malocclusions. Chen et al. (2015) showed that the prolonged use of the nursing bottle may contribute for the inadequate development of the jaw besides interfering in the muscular functioning and in the tongue, both decisive for the development of malocclusions. 


\begin{tabular}{|c|c|c|c|c|c|c|c|c|c|c|c|c|c|c|c|c|c|c|c|c|c|c|c|c|}
\hline & 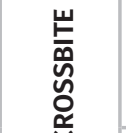 & 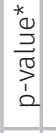 & 㟯 & & & $\begin{array}{l}\stackrel{0}{+} \\
\text { ț }\end{array}$ & & & $\stackrel{m}{m}$ & & & 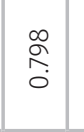 & & & $\begin{array}{l}0 \\
\text { ñ } \\
0\end{array}$ & & & $\underset{O}{E}$ & & & 瓷 & & & $\stackrel{m}{\check{c}}$ \\
\hline & $\frac{0}{\alpha}$ & ১० & & $\stackrel{\infty}{\sim}$ & $\hat{\sigma}$ & & $\overline{6}$ & $\stackrel{\circ}{\infty}$ & & बे & $\grave{\lambda}$ & & $\stackrel{+}{+}$ & $\stackrel{\circ}{\circ}$ & & $\stackrel{\circ}{i}$ & $\stackrel{\infty}{\infty}$ & & $\check{\grave{v}}$ & $\stackrel{0}{\sim}$ & & $\widehat{\infty}$ & gે & \\
\hline & $\stackrel{5}{\ll}$ & $=$ & & $\sigma$ & $\stackrel{ \pm}{\sim}$ & & $F$ & $\stackrel{\infty}{m}$ & & $\stackrel{\sim}{\sim}$ & $\stackrel{\sim}{\sim}$ & & $m$ & ה & & $\sim$ & $\underset{f}{0}$ & & 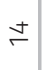 & 의 & & $\stackrel{\infty}{+}$, & $\wedge$ & \\
\hline & 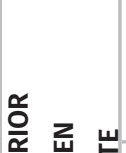 & 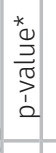 & $\begin{array}{l}\bar{o} \\
\stackrel{0}{0} \\
\dot{0}\end{array}$ & & & $\underset{\check{C}}{\stackrel{2}{0}}$ & . & & $\begin{array}{l}\infty \\
\infty \\
o \\
0\end{array}$ & 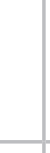 & . & ڤ్ & 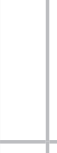 & 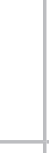 & $\underset{\hat{O}}{E}$ & & & $\begin{array}{l}\overline{0} \\
\infty \\
0 \\
0\end{array}$ & & & 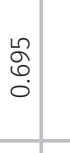 & & & 苞 \\
\hline & $\sum_{<}^{\mathbb{5}} \overline{0} \overline{\overline{0}}$ & ○ & & $\stackrel{尺}{\check{r}}$ & 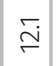 & & $\stackrel{\circ}{\circ}$ & $\stackrel{\infty}{\stackrel{\infty}{f}}$ & & $\stackrel{\stackrel{a}{p}}{\stackrel{m}{\sigma}}$ & $\stackrel{\infty}{p}$ & & $\stackrel{\stackrel{\leftrightarrow}{\sim}}{ }$ & م્م & & $\hat{\varphi}$ & 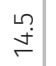 & & $\stackrel{\Im}{\dot{J}}$ & $\stackrel{\leftrightarrow}{m}$ & & 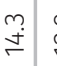 & $\stackrel{\leftrightarrow}{\stackrel{\mathrm{j}}{ }}$ & \\
\hline & & $=$ & & F & $\stackrel{\circ}{m}$ & & $\stackrel{\infty}{\rightleftharpoons}$ & 8 & & $\stackrel{\infty}{\sim}$ & 号 & & Б & के & & 0 & $\bar{\infty}$ & 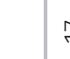 & $=$ & 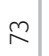 & & $\curvearrowright$ & $m$ & \\
\hline $\begin{array}{l}\text { zo } \\
\text { 틑 }\end{array}$ & 음 & 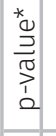 & 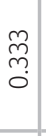 & & & $\underset{0}{\stackrel{E}{i}}$ & & & 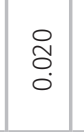 & & & हुํ. & & & 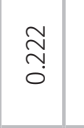 & & & $\underset{\substack{\mathcal{T} \\
0}}{0}$ & & & $\begin{array}{l}\overline{0} \\
0 \\
0\end{array}$ & & & 음 \\
\hline 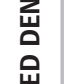 & 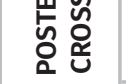 & $\circ^{\circ}$ & & $\stackrel{\circ}{\mathrm{i}}$ & 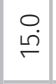 & & $\stackrel{\infty}{\stackrel{\sim}{\sim}}$ & $\stackrel{\circ}{\sim}$ & & $\stackrel{\circ}{\infty}$ & $\begin{array}{l}\stackrel{\sim}{\sim} \\
\stackrel{+}{\sim}\end{array}$ & & $\stackrel{\stackrel{?}{\rightleftharpoons}}{\rightleftharpoons}$ & $\stackrel{\sim}{m}$ & & $\stackrel{\circ}{\circ}$ & $\stackrel{さ}{\check{I}}$ & & 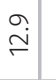 & $\stackrel{\infty}{\stackrel{\infty}{\digamma}}$ & & $\stackrel{\circ}{\circ}$ & $\begin{array}{l}\circ \\
\stackrel{9}{\circ}\end{array}$ & \\
\hline$\underset{\underline{\Sigma}}{\stackrel{X}{\Sigma}}$ & & $\subset$ & & a & $\hat{m}$ & & $\approx$ & Б & & $\bullet$ & ક & & 字 & $\approx$ & & $\sim$ & 8 & & $\stackrel{\llcorner}{\llcorner}$ & $\widetilde{\sigma}$ & & 8 & $\sigma$ & \\
\hline 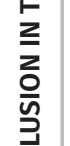 & $\stackrel{\vec{\omega}}{\underline{\omega}}$ & \begin{tabular}{|c|}
$*$ \\
0 \\
\\
0 \\
0 \\
0 \\
2 \\
\end{tabular} & @̊ & & & 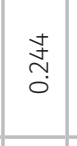 & & & $\begin{array}{l}\bar{\wp} \\
0\end{array}$ & & & $\begin{array}{l}0 \\
\stackrel{0}{0} \\
\infty \\
0\end{array}$ & & & 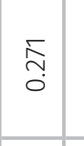 & & & 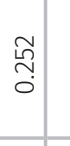 & & & $\underset{\widetilde{m}}{\overline{0}}$ & & & 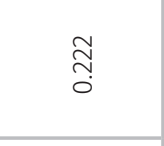 \\
\hline  & 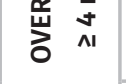 & ১० & & 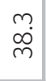 & $\begin{array}{l}\sigma \\
\dot{m}\end{array}$ & & $\stackrel{\infty}{\stackrel{m}{m}}$ & $\stackrel{n}{\mathrm{~m}}$ & & 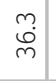 & $\stackrel{\bar{\phi}}{m}$ & & $\begin{array}{l}0 \\
\dot{\infty} \\
m\end{array}$ & $\begin{array}{l}\stackrel{\sigma}{\mathrm{m}} \\
\mathrm{m}\end{array}$ & & $\stackrel{\circ}{\circ}$ & $\begin{array}{l}a \\
\infty \\
m\end{array}$ & & $\stackrel{\circ}{m}$ & $\stackrel{m}{m}$ & & $\underset{m}{\stackrel{n}{m}}$ & $\stackrel{\leftrightarrow}{\vec{\gamma}}$ & \\
\hline & & $=$ & & $\stackrel{n}{\kappa}$ & $\bar{\infty}$ & & F & $\hat{m}$ & & $\bar{\sigma}$ & $\infty$ & & $\stackrel{ \pm}{\simeq}$ & $N$ & & $a$ & $\stackrel{+}{\stackrel{2}{*}}$ & & $\bar{m}$ & $\stackrel{\varrho}{\circ}$ & & $\stackrel{0}{0}$ & $\stackrel{\bullet}{m}$ & \\
\hline & 岀 & 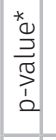 & 胥 & & & $\begin{array}{c}\stackrel{8}{0} \\
\infty \\
0 \\
0\end{array}$ & & & \begin{tabular}{l}
\multirow{2}{*}{} \\
ò
\end{tabular} & & & है & & & $\begin{array}{l}0 \\
\text { ò } \\
0\end{array}$ & & & 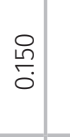 & & & 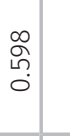 & & & 今ે \\
\hline & 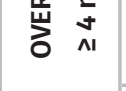 & ১० & & $\frac{a}{\dot{m}}$ & $\mid \begin{array}{l}n \\
\stackrel{n}{0} \\
\dot{m}\end{array}$ & & $\begin{array}{l}\infty \\
\dot{m}\end{array}$ & $\stackrel{\circ}{\stackrel{f}{m}}$ & & $\stackrel{\circ}{\stackrel{p}{m}}$ & $\begin{array}{l}\stackrel{\sim}{+} \\
\stackrel{f}{m}\end{array}$ & & $\stackrel{\circ}{m}$ & के. & & $\stackrel{m}{m}$ & $\stackrel{ \pm}{m}$ & & $\begin{array}{l}\text { Tै } \\
\text { ơ }\end{array}$ & $\stackrel{\sim}{\tilde{m}}$ & & $\stackrel{m}{\stackrel{m}{m}}$ & $\stackrel{m}{m}$ & \\
\hline & & $=$ & & 8 & \pm & & 寸 & $\risingdotseq$ & & ธ & $\alpha$ & & $\stackrel{\hat{\rho}}{\circ}$ & 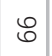 & & $a$ & $\stackrel{\infty}{\underset{\sim}{\sim}}$ & & $\hat{m}$ & 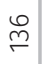 & & f̊ & \pm & \\
\hline & 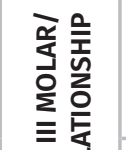 & 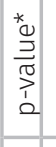 & $\begin{array}{l}\bar{\sigma} \\
\stackrel{0}{0}\end{array}$ & & & 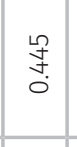 & & & 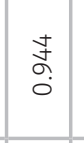 & & & 号 & & & $\frac{\sigma}{0}$ & & & 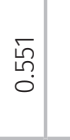 & & & ֻ. & & & ्ֻञ \\
\hline & 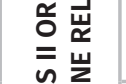 & ๙० & & $\begin{array}{l}0 \\
0 \\
0 \\
+\end{array}$ & $\stackrel{m}{\dot{s}}$ & & $\bar{g}$ & 家 & & 字 & ֶָg & & $\stackrel{9}{\dot{\tau}}$ & ก̊. & & 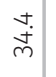 & $\begin{array}{l}\tilde{y} \\
\dot{\sigma}\end{array}$ & & 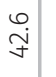 & $\begin{array}{c}\infty \\
\dot{q} \\
\dot{q}\end{array}$ & & $\begin{array}{l}q \\
\text { f }\end{array}$ & $\begin{array}{l}\stackrel{P}{\dot{y}} \\
\stackrel{y}{4}\end{array}$ & \\
\hline & & $\subset$ & & 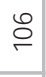 & n & & $\mathbb{N}$ & $\underline{\sigma}$ & & $\mathscr{\infty}$ & $\stackrel{\infty}{\sim}$ & & $\underset{\mathcal{F}}{\sim}$ & $\stackrel{\infty}{\circ}$ & & $\digamma$ & $\approx$ & & Ұ & ळे & & 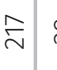 & m & \\
\hline & 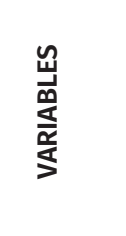 & & $\begin{array}{l}\text { 㞻 } \\
\text { 之े } \\
\text { 岕 }\end{array}$ & $\frac{\frac{\theta}{\pi}}{\frac{\pi}{2}}$ & 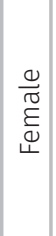 & 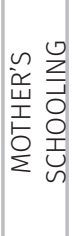 & $\begin{array}{l}\stackrel{n}{\sigma} \\
\stackrel{\Delta}{\Delta} \\
\infty \\
v_{1}\end{array}$ & 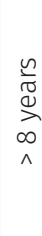 & 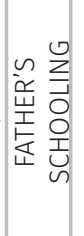 & 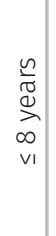 & $\begin{array}{l}\stackrel{n}{\tilde{\sigma}} \\
\stackrel{\Delta}{\triangle} \\
\infty \\
\wedge\end{array}$ & 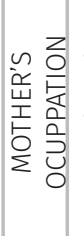 & 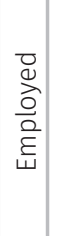 & 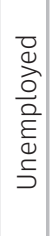 & 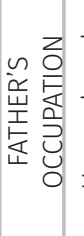 & 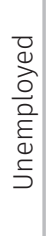 & 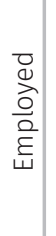 & 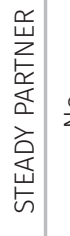 & 울 & $\stackrel{\varrho}{\nu}$ & 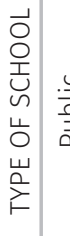 & $\frac{. \breve{a}}{\frac{a}{a}}$ & 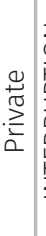 & 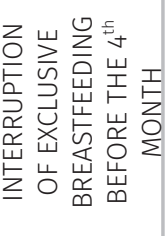 \\
\hline
\end{tabular}




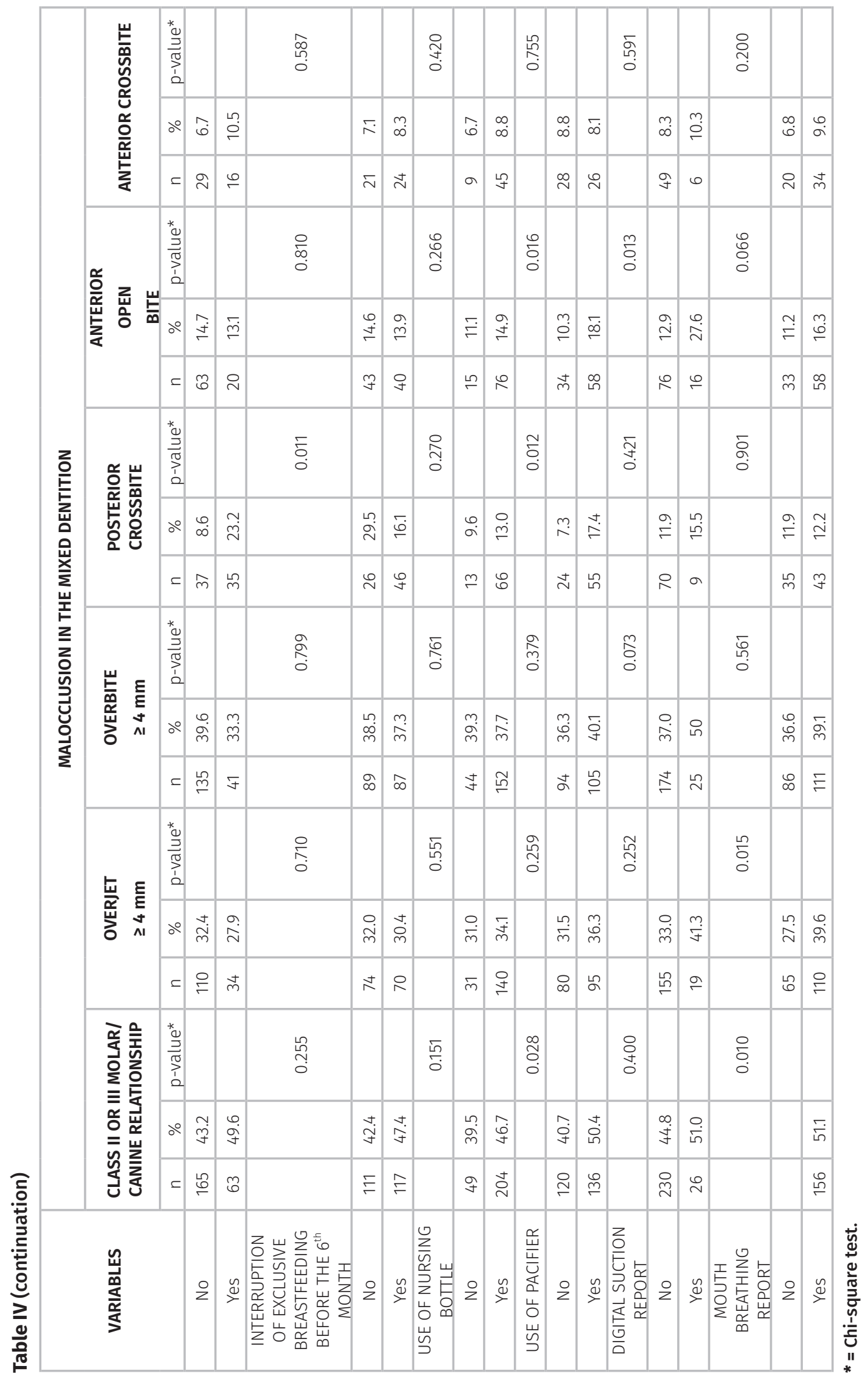


Table V. Results of the multivariate analysis for Class II or III molar/canine relationship, overjet $\geq 4 \mathrm{~mm}$, posterior crossbite and anterior open bite. 6-year-old schoolchildren. Palhoça/SC, Brazil.

\begin{tabular}{|c|c|c|c|c|c|c|}
\hline VARIABLES & $\mathbf{P R}_{\mathrm{c}}$ & $\mathrm{Cl} 95 \%$ & $\begin{array}{c}\text { p- } \\
\text { value }\end{array}$ & $\mathbf{P R}_{\mathrm{a}}$ & $\mathrm{Cl} 95 \%$ & p-value \\
\hline \multicolumn{7}{|c|}{ CLASS II OR III MOLAR/CANINE RELATIONSHIP } \\
\hline MOTHER'S OCCUPATION & & & 0.050 & & & 0.166 \\
\hline Unemployed & 1.00 & & & 1.00 & & \\
\hline Employed & 0.83 & $0.69 ; 1.00$ & & 0.86 & $0.7 ; 1.06$ & \\
\hline FATHER'S OCCUPATION & & & 0.199 & & & 0.081 \\
\hline Employed & 1.00 & & & 1.00 & & \\
\hline Unemployed & 0.74 & $0.45 ; 1.21$ & & 0.59 & $0.32 ; 1.07$ & \\
\hline $\begin{array}{c}\text { INTERRUPTION OF EXCLUSIVE } \\
\text { BREASTFEEDING BEFORE THE } 4^{\text {th }} \mathrm{MONTH}\end{array}$ & & & 0.200 & & & 0.901 \\
\hline No & 1.00 & & & 1.00 & & \\
\hline Yes & 1.14 & $0.93 ; 1.41$ & & 1.01 & $0.80 ; 1.28$ & \\
\hline USE OF NURSING BOTTLE & & & 0.151 & & & 0.591 \\
\hline No & 1.00 & & & 1.00 & & \\
\hline Yes & 1.18 & $0.93 ; 1.50$ & & 1.07 & $0.81 ; 1.41$ & \\
\hline USE OF PACIFIER & & & 0.028 & & & 0.030 \\
\hline No & 1.00 & & & 1.00 & & \\
\hline Yes & 1.23 & $1.03 ; 1.48$ & & 1.27 & $1.02 ; 1.58$ & \\
\hline MOUTH BREATHING REPORT & & & 0.010 & & & 0.012 \\
\hline No & 1.00 & & & 1.00 & & \\
\hline Yes & 1.33 & $1.10 ; 1.61$ & & 1.30 & $1.05 ; 1.61$ & \\
\hline \multicolumn{7}{|c|}{ OVERJET $\geq 4 \mathrm{~mm}$} \\
\hline STEADY PARTNER & & & 0.150 & & & \\
\hline Yes & 1.00 & & & 1.00 & & \\
\hline No & 1.23 & $0.93 ; 1.64$ & & 1.23 & $0.93 ; 1.63$ & \\
\hline MOUTH BREATHING REPORT & & & 0.015 & & & 0.012 \\
\hline No & 1.00 & & & 1.00 & & \\
\hline Yes & 1.43 & $1.11 ; 1.85$ & & 1.41 & $1.09 ; 1.82$ & \\
\hline \multicolumn{7}{|c|}{ POSTERIOR CROSSBITE } \\
\hline TYPE OF SCHOOL & & & 0.021 & & & 0.040 \\
\hline Private & 1.73 & $1.09 ; 2.78$ & & 1.59 & $1.01 ; 2.53$ & \\
\hline Public & 1.00 & & & 1.00 & & \\
\hline $\begin{array}{l}\text { INTERRUPTION OF EXCLUSIVE } \\
\text { BREASTFEEDING BEFORE THE } 4^{\text {th }} \mathrm{MONTH}\end{array}$ & & & 0.010 & & & 0.011 \\
\hline No & 1.00 & & & 1.00 & & \\
\hline Yes & 2.68 & $1.76 ; 4.10$ & & 2.23 & $1.44 ; 3.45$ & \\
\hline USE OF PACIFIER & & & 0.012 & & & 0.016 \\
\hline No & 1.00 & & & 1.00 & & \\
\hline Yes & 2.39 & $1.52 ; 3.76$ & & 2.13 & $1.30 ; 3.51$ & \\
\hline
\end{tabular}


Table V (continuation)

\begin{tabular}{|c|c|c|c|c|c|c|}
\hline VARIABLES & $\mathbf{P R}_{\mathrm{c}}$ & CI $95 \%$ & $\begin{array}{c}\mathrm{p}- \\
\text { value }\end{array}$ & $\mathbf{P R}_{\mathrm{a}}$ & $\mathrm{Cl} 95 \%$ & p-value \\
\hline \multicolumn{7}{|c|}{ ANTERIOR OPEN BITE } \\
\hline GENDER & & & 0.081 & & & 0.098 \\
\hline Male & 1.00 & & & 1.00 & & \\
\hline Female & 0.68 & $0.44 ; 1.05$ & & 0.67 & $0.42 ; 1.06$ & \\
\hline MOTHER'S SCHOOLING & & & 0.112 & & & 0.152 \\
\hline$>8$ years & 1.00 & & & 1.00 & & \\
\hline$\leq 8$ years & 0.67 & $0.41 ; 1.11$ & & 0.69 & $0.41 ; 1.14$ & \\
\hline USE OF PACIFIER & & & 0.016 & & & 0.012 \\
\hline No & 1.00 & & & 1.00 & & \\
\hline Yes & 1.75 & $1.18 ; 2.60$ & & 2.65 & $1.56 ; 4.50$ & \\
\hline DIGITAL SUCTION REPORT & & & 0.013 & & & 0.045 \\
\hline No & 1.00 & & & 1.00 & & \\
\hline Yes & 2.14 & $1.34 ; 3.42$ & & 1.81 & $1.03 ; 3.18$ & \\
\hline MOUTH BREATHING REPORT & & & 0.066 & & & 0.191 \\
\hline No & 1.00 & & & 1.00 & & \\
\hline Yes & 1.45 & $0.97 ; 2.16$ & & 1.35 & $0.84 ; 2.23$ & \\
\hline
\end{tabular}

$\mathrm{PR}_{\mathrm{c}}=$ Crude prevalence ratio. $\mathrm{PR}_{\mathrm{a}}=$ Adjusted prevalence ratio. $\mathrm{Cl} 95 \%$ = Confidence interval at $95 \%$. The variable "father's schooling" presented collinearity with the variable "type of school" $(p<0.011)$ in the model for posterior crossbite. It was opted to remove the variable "father's schooling".

The report of mouth breathing showed to be an important factor associated to the development of malocclusion, since it has been associated with class II or III molar/ canine relationship, with overjet $\geq 4 \mathrm{~mm}$ and with posterior crossbite, corroborating with the literature (Bueno et al. 2013, Moimaz et al. 2014, Grippaudo et al. 2016). Moimaz et al. (2014) found relationship between mouth breathing and the development of posterior crossbite, while Grippaudo et al. (2016) considered mouth breathing as a risk factor for malocclusions in general. Bueno et al. (2013) assessed the nasal air flow and demonstrated association mouth breathing and the development of posterior crossbite, as well as increased deficiency of jaw size. The mechanism of the relationship between mouth breathing and the occurrence of malocclusions may be explained by the obstruction of airways and consequent alteration in tongue and lips posture (Sousa et al. 2005).

A limitation of this study refers to its design. Although using data from a cohort study, the analysis performed here had a cross-sectional design, which allowed studying the associations between the different phenomena, but not establishing cause-effect relationship. Another aspect to be considered is that, because children were in transition from primary to permanent dentition, typical of the studied age, the possibility of measurement bias may be considered. This imposes caution in the analysis and interpretation of the results.

It was possible to conclude that the prevalence of malocclusions in the mixed dentition was high in the studied population. The interruption of exclusive breastfeeding before the fourth month showed to be independently associated 
with posterior crossbite. The use of pacifier was associated with the occurrence of class II or III molar/canine relationship, posterior crossbite and anterior open bite. Digital suction showed to be associated to anterior open bite and mouth breathing, class II or III molar/canine relationship, increased overjet and anterior open bite.

\section{Acknowledgments}

We thank PROSUC/CAPES, Brazil for granting doctoral scholarships to the authors ET and RDN. We thank FAPESC for funding this study.

\section{REFERENCES}

AMARAL CC, COSTA VPP, AZEVEDO MS, PINHEIRO RT, DEMARCO FF \& GOETTEMS ML. 2017. Perinatal health and malocclusions in preschool children: findings from a cohort of adolescent mothers in Southern Brazil. Am J Orthod Dentofacial Orthop 152(5): 613-621.

AMARAL LJX, SALES SS, CARVALHO DPSRP, CRUZ GKP, AZEVEDO IC \& FERREIRA JÚNIOR MA. 2015. Fatores que influenciam na interrupção do aleitamento materno exclusivo em nutrizes. Rev Gaucha Enferm 36: 127-134.

BAUMAN JM, SOUZA JGS, BAUMAN CD \& FLÓRIO FM. 2018. Epidemiological pattern of malocclusion in Brazilian preschoolers. Cien Saude Coletiva 23(11): 3861-3868.

BORONAT-CATALA M, MONTIEL-COMPANY JM, BELLOT-ARCIS C, ALMERICH-SILLA JM \& CATALA-PIZARRO M. 2017. Association between duration of breastfeeding and malocclusions in primary and mixed dentition: a systematic review and meta-analysis. Sci Rep 7(1): 5048.

BRASIL. 2011. Pesquisa Nacional de Saúde Bucal. Resultados Principais. Brasília, 2011. http://dab.saude. gov.br/CNSB/sbbrasil/arquivos/projeto_sb2010_ relatorio_final.pdf. Acessed August 16 2017.

BUENO SB, BITTAR TO, VAZQUEZ FL, MENEGHIM MC \& PEREIRA AC. 2013. Association of breastfeeding, pacifier use, breathing pattern and malocclusions in preschoolers. Rev Dental Press J Orthod 18(1): e1-6.

CHEN X, XIA B \& GE L. 2015. Effects of breast-feeding duration, bottle-feeding duration and non-nutritive sucking habits on the occlusal characteristics of primary dentition. BMC Pediatr 15: 46.

CORREA-FARIA P, MARTINS-JUNIOR PA, VIEIRA-ANDRADE RG, MARQUES LS \& RAMOS-JORGE ML. 2013. Factors associated with the development of early childhood caries among Brazilian preschoolers. Braz Oral Res 27(4): 356-362.

GERMA A, CLEMENT C, WEISSENBACH M, HEUDE B, FORHAN A, MARTIN-MARCHAND L, BONET M, VITAL S, KAMINSKI M \& NABET C. 2016. Early risk factors for posterior crossbite and anterior open bite in the primary dentition. Angle Orthod 86(5): 832-838.

GRIPPAUDO C, PAOLANTONIO EG, ANTONINI G, SAULLE R, LA TORRE G \& DELI R. 2016. Association between oral habits, mouth breathing and malocclusion. Acta Otorhinolaryngol Ital 36(5): 386-394.

LANDIS JR \& KOCH GG. 1977. The measurement of observer agreement for categorical data. Biometrics 33: 159-174.

LOPES-FREIRE GM, CARDENAS AB, SUAREZ DE DEZA JE, USTRELLTORRENT JM, OLIVEIRA LB \& QUESADA BOJ JR. 2015. Exploring the association between feeding habits, non-nutritive sucking habits, and malocclusions in the deciduous dentition. Prog Orthod 16: 43.

MOIMAZ SA, GARBIN AJ, LIMA AM, LOLLI LF, SALIBA O \& GARBIN CA. 2014. Longitudinal study of habits leading to malocclusion development in childhood. BMC Oral Health 14: 96.

PERES KG, CASCAES AM, PERES MA, DEMARCO FF, SANTOS IS, MATIJASEVICH A \& BARROS AJD. 2015. Exclusive breastfeeding and risk of dental malocclusion. Pediatrics 136(1): e60-67.

PERES KG, OLIVEIRA LATORRE MR, SHEIHAM A, PERES MA, VICTORA CG \& BARROS FC. 2007. Social and biological early life influences on the prevalence of open bite in Brazilian 6-year-olds. Int J Paediatr Dent 17(1): 41-49.

PERES KG, PERES MA, ARAUJO CL, MENEZES AM \& HALLAL PC. 2009. Social and dental status along the life course and oral health impacts in adolescents: a population-based birth cohort. Health Qual Life Outcomes 7: 95.

PERES KG, TRAEBERT E \& MARCENES W. 2002. Differences between normative criteria and self-perception in the assessment of malocclusion. Rev Saude Publica 36(2): 230-236.

PERES MA, TRAEBERT J \& MARCENES W. 2001. Calibration of examiners for dental caries epidemiologic studies. Cad Saude Publica 17(1): 153-159.

SOUSA F, TAVEIRA G, ALMEIDA R \& PADILHA W. 2004. O aleitamento materno e sua relação com hábitos deletérios e maloclusão dentária. Pesq Bras Odontoped Clin Integ 4(3): 211-216.

SOUSA JB, ANSELMO-LIMA WT, VALERA FC, GALLEGO AJ \& MATSUMOTO MA. 2005. Cephalometric assessment of the 
mandibular growth pattern in mouth-breathing children. Int J Pediatr Otorhinolaryngol 69(3): 311-317.

SOUSA RV, RIBEIRO GL, FIRMINO RT, MARTINS CC, GRANVILLEGARCIA AF \& PAIVA SM. 2014. Prevalence and associated factors for the development of anterior open bite and posterior crossbite in the primary dentition. Braz Dent J 25(4): 336-342.

SUMMERS CJ. 1971. The occlusal index: a system for identifying and scoring occlusal disorders. Am J Orthod 59(6): 552-567.

TRAEBERT J, LUNARDELLI SE, MARTINS LGT, SANTOS K, NUNES RD, LUNARDELLI AN \& TRAEBERT E. 2018. Methodological description and preliminary results of a cohort study on the influence of the first 1,000 days of life on the children's future health. An Acad Bras Cienc 90: 3105-3114.

WHO - WORLD HEALTH ORGANIZATION. 2013. World Dental Federation. Oral Health Surveys: Basic Methods. $5^{\text {th }}$ ed., Geneva, Switzerland, 123 p.

\section{How to cite}

TRAEBERT E, ZANINI FA, NUNES RD \& TRAEBERT J. 2020. Nutritional and non-nutritional habits and occurrence of malocclusions in the mixed dentition. An Acad Bras Cienc 92: e20190833. DOI 10.1590/00013765202020190833.

Manuscript received on July 27, 2019; accepted

for publication on September 25, 2019

\section{ELIANE TRAEBERT ${ }^{1,2}$}

https://orcid.org/0000-0001-9667-7216

\section{FRANCIELLE A. ZANINI}

https://orcid.org/0000-0002-1374-6026

\section{RODRIGO DIAS NUNES ${ }^{1,2}$}

https://orcid.org/0000-0002-2261-8253

\section{JEFFERSON TRAEBERT ${ }^{1,2}$}

https://orcid.org/0000-0002-7389-985X

${ }^{1}$ Postgraduate Program in Health Sciences, Universidade do Sul de Santa Catarina, Avenida Pedra Branca, 25, Cidade Universitária Pedra Branca, 88132-270 Palhoça, SC, Brazil ${ }^{2}$ School of Medicine, Universidade do Sul de Santa Catarina, Avenida Pedra Branca, 25, Cidade Universitária Pedra Branca, 88132-270 Palhoça, SC, Brazil

Correspondence to Jefferson Traebert

E-mail: jefferson.traebert@gmail.com

\section{Author contributions}

ET, FAZ, RDN and JT contributed to the conception and design, data collection, analysis and interpretation of data, the review and approval of the final version of the article.

\section{(cc) BY}

